\title{
Toxigenic Status of Staphylococcus aureus Isolated from Bovine Raw Milk and Minas Frescal Cheese in Brazil
}

\author{
EDNA FROEDER ARCURI, $, 1,2 *$ FABIOLA FONSECA ÂNGELO,${ }^{3}$ MARTA FONSECA MARTINS GUIMARÃES, ${ }^{1}$ \\ RÉGINE TALON, ${ }^{4}$ MARIA DE FATIMA BORGES,${ }^{5}$ SABINE LEROY,${ }^{4}$ GÉRARD LOISEAU, ${ }^{2}$ \\ CARLA CHRISTINE LANGE, ${ }^{1}$ NÉLIO JOSÉ DE ANDRADE, ${ }^{3}$ AND DIDIER MONTET ${ }^{2}$
}

\begin{abstract}
${ }^{1}$ Embrapa Dairy Cattle, Rua Eugenio do Nascimento 610, Bairro Dom Bosco, 36038-330, Juiz de Fora, Minas Gerais, Brazil; ${ }^{2}$ Centre de Coopération Internationale en Recherche Agronomique pour le Développement, UMR 95 Qualisud, TA B-95/16, 73 rue Jean-François Breton, 34398 Montpellier, France, ${ }^{3}$ Universidade Federal de Viçosa, Av. P. H. Rolfs, s/n, 36570-000, Viçosa, Minas Gerais, Brazil;; ${ }^{4}$ Institut National de la Recherche Agronomique, UR 454 Microbiologie, F-63122 Saint-Genès-Champanelle, France; and ${ }^{5}$ Embrapa Tropical Agroindustry, Caixa Postal 3761, 60511-110 Fortaleza, Ceará, Brazil
\end{abstract}

MS 10-279: Received 5 July 2010/Accepted 10 September 2010

\begin{abstract}
A group of 291 Staphylococcus aureus isolates from mastitic cow's milk $(n=125)$, bulk tank milk $(n=96)$, and Minas frescal cheese $(n=70)$ were screened for staphylococcal enterotoxin (SE) genes (sea, seb, sec, sed, see, seg, seh, sei, selj, and sell) and for the tst- 1 gene encoding staphylococcal toxic shock syndrome toxin 1 by PCR assay. A total of 109 (37.5\%) of the isolates were positive for at least one of these 11 genes, and 23 distinct genotypes of toxin genes were observed. Of the $S$. aureus isolates bearing SE genes, 17 (13.6\%) were from mastitic cow's milk, 41 (41.7\%) were from bulk tank milk, and 51 (72.9\%) were from Minas frescal cheese. The occurrence of exclusively more recently described SE genes (seg through sell) was considerably higher (87 of 109 PCR-positive strains) than that of classical SE genes (sea through see, 15 strains). The SE genes most commonly detected were $s e g$ and $s e i$; they were found alone or in different combinations with other toxin genes, but in $60.8 \%$ of the cases they were codetected. No strain possessed see. The tst-l gene was found in eight isolates but none from mastitic cow's milk. Macrorestriction analysis of chromosomal DNA from 89 S. aureus isolates positive for SE gene(s) was conducted with the enzyme SmaI. Fifty-five distinct pulsed-field gel electrophoresis patterns were found, demonstrating a lack of predominance of any specific clone. A second enzyme, ApaI, used for some isolates was less discriminating than SmaI. The high genotype diversity of potential toxigenic S. aureus strains found in this study, especially from Minas frescal cheese, suggests various sources of contamination. Efforts from the entire production chain are required to improve consumer safety.
\end{abstract}

Staphylococcus aureus is a human and animal pathogen that can produce numerous toxins, including the pyrogenic toxins staphylococcal enterotoxins (SEs) and toxic shock syndrome toxin 1 (TSST-1) (39). SEs are a leading cause of gastroenteritis and vomiting resulting from consumption of contaminated food (22). SE-contaminated milk and milk products often are involved in outbreaks. Milk and soft cheese are good substrates for S. aureus, and when an enterotoxigenic strain exceeds $10^{5} \mathrm{CFU} / \mathrm{ml}$ or $\mathrm{CFU} / \mathrm{g}$, it may produce sufficient amount of toxin to cause intoxication symptoms (3).

The SEs are a group of heat stable and pepsin resistant exotoxins encoded by genes in the chromosome, pathogenicity island, phages, or plasmids (10). To date, 19 types of SEs, divided into two groups, have been reported and their genes described: the classical SEs (SEA, SEB, SEC, SED, and SEE) and the more recently described SEs, including SE-like (SEl) toxins (SEG, SEH, SEI, SEIJ, SEIK, SEIL, SEIM, SEIN, SEIO, SEIP, SEIQ, SEIR, SEIU, and SEIV)

* Author for correspondence. Tel: (33) 4676157 28; Fax: (33) 4676144 44; E-mail: edna@cnpgl.embrapa.br.
$(10-12,16,21,23,25)$. The SEls are toxins that do not have emetic activity or have not been tested for emetic activity, a defined property of SEs (17). SEF, which was discovered in 1980, was renamed TSST-1 because of the lack of evidence of emetic activity in monkeys (3). TSST-1 causes toxic shock syndrome $(3,38)$.

S. aureus is ubiquitous; it is usually present on the skin and mucosa of animals and humans and is frequently associated with bovine mastitis (35). Without proper hygienic or sanitary precautions, contamination can occur throughout the milk processing chain. In Brazil, several researchers have reported recovery of $S$. aureus from mastitic bovine milk $(15,30,43)$ and high counts in raw milk and Minas frescal cheese, with many samples exceeding $10^{5} \mathrm{CFU} / \mathrm{g}(6,27,29)$. Outbreaks of staphylococcal food poisoning associated with consumption of Minas frescal cheese containing classical enterotoxins have been reported $(7,34)$. Of the more recently described SEs, only SEH has been associated with food poisoning, and one case was associated with cheese consumption in Brazil (28). However, few studies are available concerning the occurrence of the newly described SE genes in S. aureus isolated from milk and/or milk products. 
TABLE 1. Primers for the detection of Staphylococcus aureus toxin genes

\begin{tabular}{|c|c|c|c|}
\hline Gene & Primer sequence $\left(5^{\prime}\right.$ to $\left.3^{\prime}\right)$ & Amplicon (bp) & Reference \\
\hline \multirow[t]{2}{*}{ sea } & ESA1: ACGATCAATTTTTACAGC & 544 & 31 \\
\hline & ESA2: TGCATGTTTTCAGAGTTAATC & & \\
\hline \multirow[t]{2}{*}{ seb } & ESB1: GAATGATATTAATTCGCATC & 416 & 31 \\
\hline & ESB2: TCTTTGTCGTAAGATAAACTTC & & \\
\hline \multirow[t]{2}{*}{$\sec$} & ESC1: GACATAAAAGCTAGGAATTT & 257 & 31 \\
\hline & ESC2: AAATCGGATTAACATTATCCA & & \\
\hline \multirow[t]{2}{*}{ sed } & ESD1: TTACTAGTTTGGTAATATCTCCTT & 334 & 31 \\
\hline & ESD2: CCACCATAACAATTAATGC & & \\
\hline \multirow[t]{2}{*}{ see } & ESE1: ATAGATAAAGTTAAAACAAGCAA & 170 & 31 \\
\hline & ESE2: TAACTTACCGTGGACCC & & \\
\hline \multirow[t]{2}{*}{ seg } & ESG1: ACGTCTCCACCTGTTGAAGG & 400 & 31 \\
\hline & ESG2: TGAGCCAGTGTCTTGCTTTG & & \\
\hline \multirow[t]{2}{*}{ seh } & ESH1: TCACATCATATGCGAAAGCAG & 357 & 31 \\
\hline & ESH2: TAGCACCAATCACCCTTTCC & & \\
\hline \multirow[t]{2}{*}{ sei } & ESI1: TGGAACAGGACAAGCTGAAA & 467 & 31 \\
\hline & ESI2: TAAAGTGGCCCCTCCATACA & & \\
\hline \multirow[t]{2}{*}{ selj } & ESJ1: CAGCGATAGCAAAAATGAAACA & 426 & 31 \\
\hline & ESJ2: TCTAGCGGAACAACAGTTCTGA & & \\
\hline \multirow[t]{2}{*}{ sell } & SEL-F: CACCAGAATCACACCGCTTA & 240 & 8 \\
\hline & SEL-R: CTGTTTGATGCTTGCCATTG & & \\
\hline \multirow[t]{2}{*}{ tst-1 } & TSST-1: AAGCCCTTTGTTGCTTGCGAC & 250 & 36 \\
\hline & TSST-2: AGCAGGGCTATAATAAGGACT C & & \\
\hline \multirow[t]{2}{*}{ femA } & GFEMAR-1: AAAAAAGCACATAACAAGCG & 132 & 19 \\
\hline & GFEMAR-2: GATAAAGAAGAAACCAGCAG & & \\
\hline
\end{tabular}

S. aureus isolates from milk and milk products can bear one or more enterotoxigenic genes, and some clones may be found. This study was conducted to investigate the distribution of classical SE genes (sea through see), the more recently described SE genes (seg through sell), and the TSST-1 gene (tst- 1 ) among $S$. aureus isolates from mastitic cow's milk and bulk tank raw milk collected at dairy farms in the Rio de Janeiro and Minas Gerais states, Brazil, and from Minas frescal cheese sold in Juiz de Fora city, Minas Gerais. The enterotoxigenic strains also were characterized by their pulsed-field gel electrophoresis (PFGE) patterns.

\section{MATERIALS AND METHODS}

Bacterial strains. A total of $291 \mathrm{~S}$. aureus isolates from mastitic cow's milk $(n=125)$, bulk tank milk $(n=96)$, and Minas frescal cheese $(n=70)$ were studied. All isolates were obtained from the bacterial collection of Embrapa Dairy Cattle (Juiz de Fora, Minas Gerais State, Brazil). The mastitic strains and the bulk tank milk strains originated from 40 and 22 dairy herds, respectively, located in the states of Rio de Janeiro and Minas Gerais, Brazil. The cheese strains were isolated from 12 brands of Minas frescal cheese made from pasteurized milk (under municipal, state, or federal inspection services) and sold in Juiz de Fora city, Minas Gerais. The bacteria from milk samples were isolated on mannitol salt agar (Difco, BD, Sparks, MD) and those from cheese samples were isolated on Baird-Parker agar (Difco, BD) (2). The bacterial isolates were first characterized by Gram staining, catalase reaction, hemolytic properties, acetoin production (Voges-Proskauer reaction), and the tube coagulase reaction (1). Isolates were then confirmed as $S$. aureus by PCR assay performed for the species-specific femA gene $(19,40)$.

DNA extraction. Total genomic DNA was obtained from pure cultures of $S$. aureus isolates by the method described by
Rosec and Gigaud (31) with some modifications. A bacterial culture was incubated overnight in brain heart infusion (BHI, Difco, BD) broth at $37^{\circ} \mathrm{C}$, and $2 \mathrm{ml}$ of this culture was centrifuged at $12,000 \times g$ for $10 \mathrm{~min}$. The cell pellet was washed two times with TE buffer (1 mM EDTA, $10 \mathrm{mM}$ Tris-HCl, pH 7.4) and resuspended in $200 \mu \mathrm{l}$ of TE buffer containing $15 \mu \mathrm{l}$ of lysostaphin (1 mg/ml; Sigma Aldrich, St. Louis, MO). After $30 \mathrm{~min}$ of incubation at $35^{\circ} \mathrm{C}, 10 \mu \mathrm{l}$ of proteinase $\mathrm{K}(20 \mathrm{mg} / \mathrm{ml})$ was added, and the suspension was incubated at $60^{\circ} \mathrm{C}$ for $20 \mathrm{~min}$. The suspension was placed in a boiling bath for $10 \mathrm{~min}$ and then centrifuged at $12,000 \times g$ for $2 \mathrm{~min}$. The supernatant containing DNA was kept frozen $\left(-20^{\circ} \mathrm{C}\right)$, and the DNA was quantified by spectrophotometry (Nanodrop ND-1000, Thermo Scientific Inc., Wilmington, DE) before PCR amplification.

PCR amplification. PCR amplification was performed for femA, 10 SE genes (sea through sell), and tst-1 using primers previously described (Table 1 ). The detection of femA was done with both a simple and a multiplex PCR assay. The genes selj and tst- 1 were detected only in separate reaction mixtures. The detection of the other SE genes was performed by multiplex PCR assay with five reaction mixtures containing primers for two genes (seg $+f e m A$, seh + sei, seb + sell, sea + sed, and sec + see $)$. The American Type Culture Collection (ATCC) S. aureus strains ATCC 19095 (sec, seh, seg, sei, and sell), ATCC 23235 (sed, seg, sei, and selj), ATCC 13565 (sea), ATCC 14458 (seb), and ATCC 27664 (see) were used as positive controls. Mixtures without DNA was used as negative controls.

The DNA amplification program was 35 cycles of $95^{\circ} \mathrm{C}$ for $30 \mathrm{~s}, 57^{\circ} \mathrm{C}$ for $30 \mathrm{~s}$, and $72^{\circ} \mathrm{C}$ for $30 \mathrm{~s}$, with a final extension at $72^{\circ} \mathrm{C}$ for $10 \mathrm{~min}$. Amplification was performed in a GeneAmp PCR System 9700 (Applied Biosystems, Foster City, CA). The reactions were carried out in a 50- $\mu$ l volume consisting of $1 \times \mathrm{PCR}$ buffer, $1.5 \mathrm{mM} \mathrm{MgCl}_{2}, 10 \mu \mathrm{M}$ concentrations of each deoxynucleoside triphosphate, $40 \mathrm{pmol}$ of each primer, $100 \mathrm{ng}$ of bacterial 
DNA, and $3 \mathrm{U}$ of Taq DNA polymerase (Invitrogen, Carlsbad, CA). PCR products were visualized by electrophoresis in a $1.8 \%$ agarose gel (wt/vol) stained with ethidium bromide, and gels were photographed under UV light (Eagle Eye II, Stratagene, La Jolla, CA).

Sequencing of amplicons. For each gene (sea through sell plus tst-1), one sample amplicon was sequenced to confirm the results. Amplicons were purified using the QIAquick PCR Purification Kit (Qiagen, Hilden, Germany), and the both strands were sequenced using the DYEnamic ET Dye Terminator Cycle Sequencing Kit (GE Healthcare Biosciences, Uppsala, Sweden) on an automated sequencer (DNA MegaBACE 1000, GE Healthcare). The partial sequences were analyzed with the LaserGene package (DNASTAR, Madison, WI). To confirm the results, we performed BLAST searches at the National Center for Biotechnology Information (Bethesda, MD).

PFGE analysis. PFGE typing of $S$. aureus strains bearing enterotoxigenic genes was performed with a modified version of the protocol proposed by Morot-Bizot et al. (20). Overnight staphylococcal culture was inoculated into fresh BHI broth and grown until it reached an optical density of 1 . After centrifugation, the pellet was resuspended in TEE (10 mM Tris $\mathrm{HCl} \mathrm{pH} 9.0$, $100 \mathrm{mM}$ EDTA, $10 \mathrm{mM}$ ethylene glycol tetraacetic acid). The suspension was mixed with an equal volume of $1 \%$ low-meltingpoint agarose (Invitrogen) and $20 \mu \mathrm{l}$ of $0.5 \mathrm{mg} / \mathrm{ml}$ lysostaphin (Sigma, St. Quentin, France). Agarose plugs were incubated in TEE with $5 \mathrm{mg} / \mathrm{ml}$ lysozyme (Sigma) and $0.05 \%$ sarkosyl for $2 \mathrm{~h}$ at $37^{\circ} \mathrm{C}$. Lysis was performed overnight in TEE containing $1 \mathrm{mg} / \mathrm{ml}$ proteinase $\mathrm{K}$ and $1 \%$ sodium dodecyl sulfate (Merck, Darmstadt, Germany) at $55^{\circ} \mathrm{C}$. The plugs were then washed three times for $60 \mathrm{~min}$ each time in TE buffer $(1 \mathrm{mM}$ EDTA, $10 \mathrm{mM}$ Tris $\mathrm{HCl}$ $\mathrm{pH}$ 8.0) containing $20 \mathrm{mM}$ phenylmethylsulphonylfluoride (Sigma). DNA in plugs was digested by $5 \mathrm{U} / \mu \mathrm{L} S m a \mathrm{I}$ or ApaI restriction enzyme (Promega, Lyon Charbonnières, France) overnight at $25^{\circ} \mathrm{C}$. Digested DNA was separated in a $1 \%$ agarose gel in $0.5 \times$ Tris-borate-EDTA buffer on a CHEF-DR III apparatus (Bio-Rad, Ivry, France). Electrophoretic conditions were 40- to 100-s pulses for $2 \mathrm{~h}$ and 5 to 35 -s pulses for $22 \mathrm{~h}$ at $14^{\circ} \mathrm{C}$ at a constant voltage of $6 \mathrm{~V} / \mathrm{cm}$ and an angle of $120^{\circ}$. Lamba DNA concatemers (Promega Corporation, Madison, WI) were used as molecular weight markers. Gels were stained with ethidium bromide, and the patterns were visualized under UV light (Gel DOC 2000, BioRad). SmaI DNA restriction bands were analyzed using the GelCompar II-Comparative Analysis of Eletrophoresis Patterns, version 2.0 (Applied Maths, Kortrijk, Belgium) with the Dice coefficient and represented by unweighted pair grouping by mathematical averaging (UPGMA) with $1.5 \%$ band tolerance. The isolates were defined as clusters or as being closely related when the PFGE patterns had at least $95 \%$ similarity, corresponding to one to three band differences on visual examination (37).

\section{RESULTS}

Detection of enterotoxin genes. The 291 isolates studied were positive for catalase, hemolysis, coagulase, and acetoin production and were all identified as $S$. aureus by the amplification of the expected 132-bp femA PCR product.

DNA from those isolates was examined for the presence of $10 \mathrm{SE}$ genes (sea, seb, sec, sed, see, seg, seh, sei, selj, sell) and $t s t-1$. Amplicons of the SE genes and $t s t-1$ were subjected to nucleotide sequencing, and their sequences had 90 to $98 \%$ homology with already published DNA sequences of the
TABLE 2. Genotype profile of Staphylococcus aureus isolated from mastitic cow's (MC) milk, farm bulk tank (FBT) milk, and Minas frescal (MF) cheese in Brazil

\begin{tabular}{|c|c|c|c|c|}
\hline \multirow[b]{2}{*}{ Genotype } & \multicolumn{4}{|c|}{ No. of isolates from: } \\
\hline & $\begin{array}{l}\text { MC } \\
\text { milk }\end{array}$ & $\begin{array}{l}\text { FBT } \\
\text { milk }\end{array}$ & $\begin{array}{c}\text { MF } \\
\text { cheese }\end{array}$ & Total \\
\hline Total no. of isolates & 125 & 96 & 70 & 291 \\
\hline $\begin{array}{l}\text { Positive for one or more toxin } \\
\text { genes }\end{array}$ & 17 & 41 & 51 & 109 \\
\hline $\begin{array}{l}\text { Positive for at least one } \\
\text { classical SE gene }\end{array}$ & 1 & 2 & 12 & 15 \\
\hline sea, seb & & & 2 & 2 \\
\hline seb & & 1 & 1 & 2 \\
\hline $\sec$ & & 1 & & 1 \\
\hline sec, sed & & & 1 & 1 \\
\hline sea, seg, tst-1 & & & 1 & 1 \\
\hline sea, seg, sei & & & 1 & 1 \\
\hline sea, seb, seh, selj & & & 1 & 1 \\
\hline seb, seh & & & 5 & 5 \\
\hline seb, seg, sei & 1 & & & 1 \\
\hline $\begin{array}{l}\text { Positive for at least one more } \\
\text { recently described SE }\end{array}$ & & & & \\
\hline gene $(\mathrm{seg}-\mathrm{sell})$ and $t$ st -1 & 16 & 39 & 39 & 94 \\
\hline seg & 4 & 1 & 5 & 10 \\
\hline seg, sei & 2 & 8 & 13 & 23 \\
\hline seg, seh & 1 & 4 & 2 & 7 \\
\hline seg, seh, sei & & 1 & & 1 \\
\hline seg, sei, selj & & 1 & 4 & 5 \\
\hline seg, sell & 1 & & & 1 \\
\hline seg, selj & & & 1 & 1 \\
\hline seh & 1 & 13 & 3 & 17 \\
\hline sei & 1 & 3 & 7 & 11 \\
\hline sei, selj & & & 2 & 2 \\
\hline selj & 4 & 2 & 1 & 7 \\
\hline sell & 2 & & & 2 \\
\hline tst-1 & & 5 & 1 & 6 \\
\hline tst-1, sei & & 1 & & 1 \\
\hline
\end{tabular}

TABLE 3. Distribution of SE genes and tst-1 among Staphylococcus aureus isolates from milk and Minas frescal cheese in Brazil

\begin{tabular}{lcccc}
\hline & \multicolumn{4}{c}{ No. (\%) of isolates } \\
\cline { 2 - 5 } & $\begin{array}{c}\text { Mastitic } \\
\text { cow's milk } \\
(n=125)\end{array}$ & $\begin{array}{c}\text { Farm bulk } \\
\text { tank milk } \\
(n=96)\end{array}$ & $\begin{array}{c}\text { Minas frescal } \\
\text { cheese } \\
(n=70)\end{array}$ & $\begin{array}{c}\text { Total } \\
(n=291)\end{array}$ \\
\hline sene & & & $5(7.1)$ & $5(1.7)$ \\
seb & $1(0.8)$ & $1(1.5)$ & $9(12.9)$ & $11(3.8)$ \\
sec & & $1(1.5)$ & $1(1.4)$ & $2(0.7)$ \\
sed & & & $1(1.4)$ & $1(0.3)$ \\
see & & & & 0 \\
seg & $9(7.2)$ & $14(14.6)$ & $28(40.0)$ & $51(17.5)$ \\
seh & $2(1.6)$ & $18(18.7)$ & $11(15.7)$ & $31(10.6)$ \\
sei & $4(3.2)$ & $13(13.5)$ & $23(32.9)$ & $40(13.7)$ \\
selj & $4(3.2)$ & $2(2.1)$ & $9(12.9)$ & $15(5.1)$ \\
sell & $3(2.4)$ & & & $3(1.0)$ \\
tst-1 & & $6(6.2)$ & $2(2.9)$ & $8(2.8)$ \\
\hline
\end{tabular}


TABLE 4. Origin, strain, toxin gene(s), and SmaI and ApaI PFGE patterns $(100 \%$ similarity) of $89 \mathrm{~S}$. aureus strains isolated from milk and Minas frescal cheese in Brazil

\begin{tabular}{|c|c|c|c|c|}
\hline Origin $^{a}$ & Strain & Gene(s) & $\begin{array}{c}\text { SmaI } \\
\text { PFGE }\end{array}$ & $\begin{array}{l}\text { ApaI } \\
\text { PFGE }\end{array}$ \\
\hline $\mathrm{MC} / \mathrm{F} 8$ & 5481 & sell & 1 & \\
\hline $\mathrm{MFC} / \mathrm{D}$ & 7835 & sell, selj & 2 & \\
\hline ВT19 & 7730 & seh & 3 & \\
\hline BT3 & 4713 & seg & 4 & $\mathrm{P} 1$ \\
\hline BT3 & 4712 & seg, seh, sei & 4 & $\mathrm{P} 1$ \\
\hline $\mathrm{MFC} / \mathrm{D}$ & 7255 & seg, seh, sei & 5 & \\
\hline $\mathrm{MFC} / \mathrm{F}$ & 7834 & sea, seg, tst-l & 6 & \\
\hline $\mathrm{MFC} / \mathrm{N}$ & 7838 & seg, sei & 7 & \\
\hline $\mathrm{MFC} / \mathrm{K}$ & 7855 & sei & 8 & $\mathrm{P} 4$ \\
\hline $\mathrm{MFC} / \mathrm{K}$ & 7862 & seg, sei & 8 & P4 \\
\hline $\mathrm{MFC} / \mathrm{K}$ & 7465 & seg, sei & 9 & \\
\hline $\mathrm{MFC} / \mathrm{H}$ & 7281 & seg & 10 & \\
\hline $\mathrm{MFC} / \mathrm{N}$ & 7325 & sei & 11 & $\mathrm{P} 4$ \\
\hline $\mathrm{MFC} / \mathrm{N}$ & 7964 & seg, sei & 11 & $\mathrm{P} 4$ \\
\hline $\mathrm{MFC} / \mathrm{N}$ & 7556 & sei & 12 & $\mathrm{P} 4$ \\
\hline MFC/I & 7582 & seg & 13 & \\
\hline $\mathrm{MC} / \mathrm{F} 10$ & 3007 & seg, seh & 14 & \\
\hline BT19 & 7735 & seg, sei & 15 & P6 \\
\hline $\mathrm{MC} / \mathrm{F} 16$ & 5595 & seg, sell & 15 & P6 \\
\hline BT22 & 7913 & seh & 16 & P6 \\
\hline ВT22 & 7915 & seg, seh & 16 & P6 \\
\hline BT22 & 7917 & seg, seh & 16 & \\
\hline ВT22 & 7919 & seg, seh & 16 & \\
\hline BT22 & 7920 & seg, seh & 16 & P6 \\
\hline ВT22 & 7921 & seh & 16 & \\
\hline BT22 & 7922 & seg, sei & 16 & \\
\hline ВT22 & 7923 & seg, sei & 16 & \\
\hline BT4 & 4726 & seg, sei & 17 & P6 \\
\hline ВТ7 & 5161 & seg, sei & 17 & P6 \\
\hline $\mathrm{MC} / \mathrm{F} 6$ & 2242 & seg, sei & 18 & \\
\hline BT1 & 4692 & seg, sei & 18 & \\
\hline $\mathrm{MC} / \mathrm{F} 19$ & 5607 & seb, seg, sei & 18 & \\
\hline MFC/I & 7825 & seg & 19 & \\
\hline BT19 & 7734 & seg, sei & 19 & \\
\hline BT19 & 7736 & seg, sei & 19 & \\
\hline $\mathrm{MFC} / \mathrm{J}$ & 7598 & $s e g, s e i$ & 20 & \\
\hline $\mathrm{MFC} / \mathrm{B}$ & 7810 & seg & 21 & \\
\hline $\mathrm{MFC} / \mathrm{B}$ & 7815 & seg & 21 & \\
\hline $\mathrm{MFC} / \mathrm{H}$ & 7271 & seg, sell, selj & 22 & \\
\hline $\mathrm{MFC} / \mathrm{H}$ & 7275 & seg, sell, selj & 22 & \\
\hline $\mathrm{MFC} / \mathrm{J}$ & 7605 & sei & 23 & \\
\hline $\mathrm{MFC} / \mathrm{N}$ & 7846 & sea, seg, sei & 24 & \\
\hline $\mathrm{MFC} / \mathrm{D}$ & 7837 & sell, selj & 25 & $\mathrm{P} 11$ \\
\hline $\mathrm{MFC} / \mathrm{J}$ & 7509 & seg, selj & 25 & $\mathrm{P} 11$ \\
\hline BT21 & 7904 & seh & 26 & $\mathrm{P} 12$ \\
\hline $\mathrm{MC} / \mathrm{F} 4$ & 2014 & seg & 27 & \\
\hline $\mathrm{MFC} / \mathrm{F}$ & 7779 & seb & 28 & \\
\hline BT13 & 5181 & seh & 29 & \\
\hline $\mathrm{MFC} / \mathrm{I}$ & 7580 & seh & 30 & $\mathrm{P} 2$ \\
\hline $\mathrm{MFC} / \mathrm{K}$ & 7848 & seh & 30 & $\mathrm{P} 2$ \\
\hline $\mathrm{MFC} / \mathrm{K}$ & 7830 & seh & 30 & \\
\hline $\mathrm{MC} / \mathrm{F} 10$ & 3006 & seh & 31 & \\
\hline $\mathrm{MFC} / \mathrm{H}$ & 7279 & selj & 32 & \\
\hline $\mathrm{MFC} / \mathrm{L}$ & 7505 & seg, seh & 33 & \\
\hline MFC/L & 7592 & seg, seh & 33 & \\
\hline $\mathrm{MFC} / \mathrm{D}$ & 7234 & sea, seb, seh, selj & 34 & \\
\hline $\mathrm{MFC} / \mathrm{F}$ & 7818 & sea, seb & 35 & P5 \\
\hline
\end{tabular}

TABLE 4. Continued

\begin{tabular}{|c|c|c|c|c|}
\hline Origin $^{a}$ & Strain & Gene(s) & $\begin{array}{c}\text { SmaI } \\
\text { PFGE }\end{array}$ & $\begin{array}{c}\text { ApaI } \\
\text { PFGE }\end{array}$ \\
\hline $\mathrm{MFC} / \mathrm{F}$ & 7832 & sea, seb & 35 & \\
\hline $\mathrm{MFC} / \mathrm{G}$ & 7780 & seb, seh & 35 & \\
\hline $\mathrm{MFC} / \mathrm{G}$ & 7782 & seb, seh & 35 & P5 \\
\hline $\mathrm{MFC} / \mathrm{G}$ & 7784 & seb, seh & 35 & \\
\hline $\mathrm{MFC} / \mathrm{G}$ & 7786 & seb, seh & 35 & \\
\hline $\mathrm{MFC} / \mathrm{G}$ & 7788 & seb, seh & 35 & \\
\hline BT11 & 4793 & $t s t-1$ & 36 & \\
\hline $\mathrm{MFC} / \mathrm{B}$ & 7932 & $t s t-1$ & 37 & \\
\hline BT19 & 7731 & seh & 38 & \\
\hline BT19 & 7732 & seh & 38 & \\
\hline BT21 & 7733 & $t s t-1$ & 39 & \\
\hline BT21 & 7908 & seh & 39 & \\
\hline MC/F6 & 7909 & seh & 39 & \\
\hline BT14 & 5482 & seh & 40 & P8 \\
\hline BT19 & 4927 & sell & 40 & \\
\hline BT20 & 7892 & seh & 41 & P7 \\
\hline BT20 & 7893 & seh & 41 & \\
\hline ВТ20 & 7890 & seh & 42 & \\
\hline BT12 & 5278 & $\mathrm{sec}$ & 43 & \\
\hline $\mathrm{MC} / \mathrm{F} 3$ & 1999 & selj & 44 & \\
\hline BT15 & 5229 & selj & 45 & \\
\hline $\mathrm{MC} / \mathrm{F} 5$ & 2221 & sei & 46 & \\
\hline BT10 & 4779 & $t s t-1$ & 47 & \\
\hline BT6 & 4752 & $s e b$ & 48 & \\
\hline MFC/I & 7590 & sec, sed & 49 & \\
\hline BT1 & 4687 & sell, tst-1 & 50 & \\
\hline BT1 & 4688 & sei & 51 & P3 \\
\hline BT13 & 5183 & sei & 51 & P3 \\
\hline MC/F5 & 1621 & selj & 52 & \\
\hline BT18 & 5175 & $t s t-1$ & 53 & \\
\hline BT1 & 4693 & sei & 54 & \\
\hline $\mathrm{MFC} / \mathrm{L}$ & 7294 & sei & 55 & \\
\hline
\end{tabular}

${ }^{a} \mathrm{MC}$, mastitic cow/farm number; MFC, Minas frescal cheese/ cheese brand; BT, bulk tank milk number.

respective genes (GenBank no. 1004003, 3237776, 5317214, M28521.1，8614569， 2862465，8614573， АВ075606.1, 5560343, 3795130).

Of the $291 \mathrm{~S}$. aureus isolates, 109 (37.5\%) were positive for one or more toxin genes (Table 2). Classical SE genes were found in combination or alone in $15(5.2 \%)$ of the strains: 1 from mastitic cow's milk, 2 from farm bulk tank milk, and 12 from Minas frescal cheese (Table 2). Of the remaining 94 positive strains (32.3\%), 87 carried only recently described SE genes (seg through sell) and 7 carried tst-1 alone or in combination with sei (Table 2).

Twenty-three distinct genotypes of the toxin genes were observed (Table 2). Of the $125 \mathrm{~S}$. aureus isolates from the mastitic cow's milk, 17 (13.6\%) were grouped in nine genotypes. The seg and sej genes predominated; seg was found in nine strains alone or in association with other enteroxin genes, and $s e j$ was found in four strains. Of the 96 S. aureus isolates from farm bulk tank milk, 41 (42.7\%) were grouped in 12 genotypes with predominance of seh. Among the 70 isolates from Minas frescal cheese, 51 $(72.9 \%)$ were grouped in 16 genotypes, and $s e g+s e i$ was the prevalent genotype. 
Table 3 shows the distribution of each toxin gene in the $S$. aureus isolates. Overall, the most frequently observed gene was seg (found in 51 of the isolates) followed by sei (40 isolates), seh (31 isolates), and selj (15 isolates). Among the classical SE genes (sea through see), seb was the most frequent (11 isolates) followed by sea (5 isolates), sec (2 isolates), and sed (1 isolate); see was not found in any isolate. The tst- 1 gene was found in eight isolates but none from mastitic cow's milk.

Diversity of the strains. The SmaI macrorestriction analysis of the $89 \mathrm{~S}$. aureus isolates carrying toxin genes revealed 55 distinct PFGE patterns, 36 of which were found in only one isolate (Table 4 and Fig. 1). Only four clusters were observed by employing a cutoff similarity value of $95 \%$, each one including two patterns $(10 / 11,18 / 19,25 / 26$, and 50/51). A large diversity of PFGE patterns was thus found among the isolates.

Nineteen SmaI patterns included more than one isolate. The strains with the same SmaI profile had the same ApaI profile (Table 4 and Fig. 2). ApaI was less discriminative; for example, the strains with SmaI profiles 15, 16, and 17 had the same ApaI profile, P6 (Table 4). The largest group with the same PFGE pattern consisted of eight isolates, all from the same origin (bulk milk tank 22), but these isolates had three distinct enterotoxin genotypes. The second largest group with the same pulsotype consisted of seven isolates from Minas frescal cheeses but from two brands of cheese, and two enterotoxin genotypes were found in samples from each brand. Very few isolates that had the same pulsotype had the same enterotoxin profile, suggesting that the genes carrying enterotoxins were on mobile elements.

\section{DISCUSSION}

In previous studies of SE genes and tst-1 in S. aureus strains, a wide range of prevalences of toxigenic strains (27.1 to $80.7 \%$ ) and great variation in the distribution of the toxin genes have been reported $(5,26,29,41)$. In our study, the toxin genes were carried by $37.5 \%$ of all tested strains, but these genes were more prevalent in strains from Minas frescal cheese $(72.9 \%, 51$ of 70 isolates) and bulk tank milk (42.7\%, 41 of 96 isolates) than from mastitic cow's milk (13.6\%, 17 of 125 isolates). A greater diversity of toxin gene combinations also was identified in isolates from Minas frescal cheese and bulk tank milk than in isolates from mastitic cow's milk. These results suggest that the sources of bacterial contamination of bulk tank milk and Minas cheese were multiple, such as raw milk collected from several cows, production and processing environments, equipment, and personnel.

The occurrence of exclusively recently described SE genes (seg through sell) was considerably higher (87 of 109 PCR-positive strains) than that of the previously characterized SE genes (15 strains). The increase in the number of potentially enterotoxigenic $S$. aureus isolates in relation to detection of new SE genes in addition to the classical SE genes has been reported for milk and/or milk product isolates by other authors $(18,29,31,44)$.
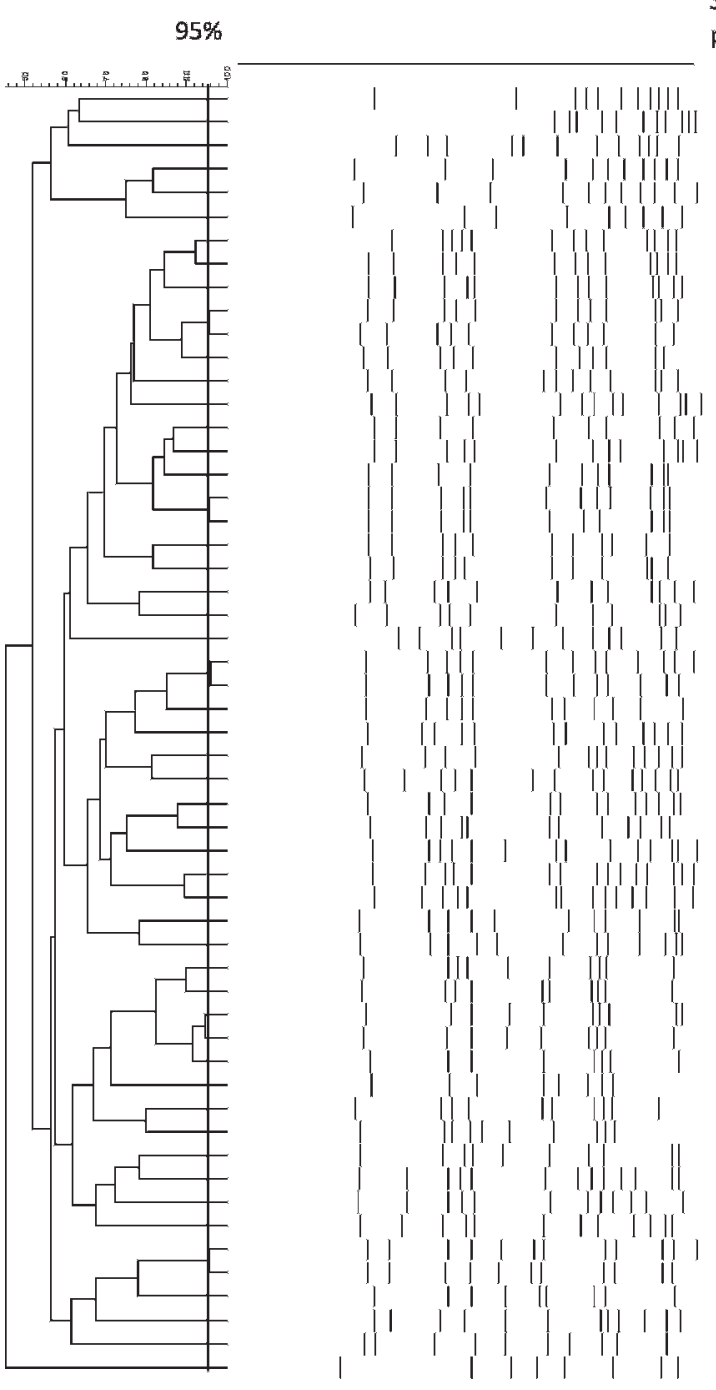

Smal-PFGE patterns

FIGURE 1. Dendogram and the $\mathrm{SmaI}$ restriction patterns identified in a set of 89 Staphylococcus aureus isolates bearing toxin genes. The strains corresponding to the Smal PFGE patterns are shown in Table 4.

The toxin genes most commonly detected in this study were seg and sei. These genes were found alone or in different combinations, but in $60.8 \%$ of these cases they occurred together. The association between seg and sei has been attributed to their location within the same gene cluster $(e g c)$ in genomic island type II $\mathrm{vSa} \beta$ (12). Rosec and Gigaud (31) found seg and sei predominantly and systematically together. However, other authors have observed them in different combinations, in agreement with our findings $(14,18,44)$. The occurrence of strains harboring $s e g$ or $s e i$ alone may be explained by mispriming due to a point mutation in one of these genes or the existence of variants in the $e g c$ cluster (4), combinations of toxin genecontaining mobile elements such as plasmids and genomic islands in the same strain, or even a new type of genetic mobile element $(24,41)$.

None of the strains in our study harbored see, in agreement with other investigations of isolates from milk and milk products in Norway (13) and from bulk tank milk in the Czech Republic (44). 


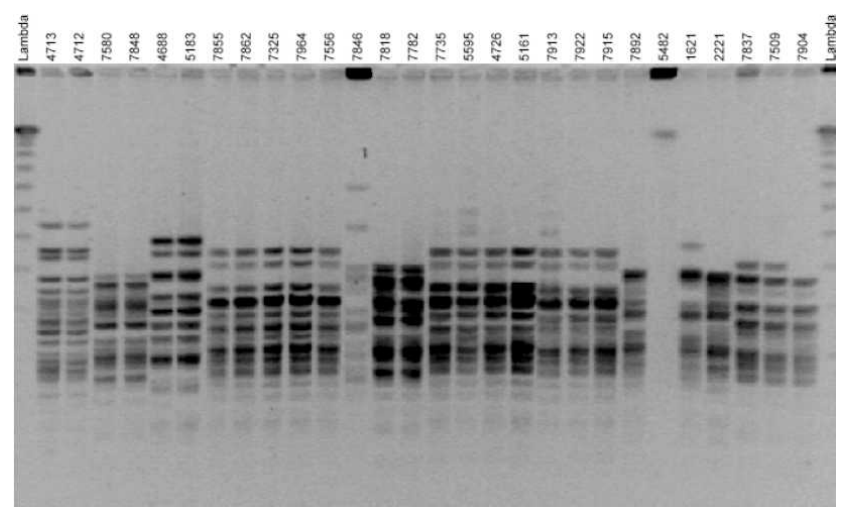

FIGURE 2. PFGE of Apal macrorestriction fragments of Staphylococcus aureus strains isolated from milk and Minas frescal cheese in Brazil.

Among the methods for molecular typing of $S$. aureus isolates, PFGE is often considered the "gold standard" because of its accuracy and reproducibility (42). In relation to PFGE, the PCR-based techniques, such as repetitive element sequence PCR, have less discriminatory power and poorer laboratory-to-laboratory reproducibility $(9,32)$. In our study, analysis of SmaI macrorestriction of genomic DNA of 89 S. aureus isolates bearing toxin genes revealed 55 PFGE patterns. Růžičková et al. (33) found 20 distinct PFGE profiles for $28 \mathrm{seh}^{+} \mathrm{S}$. aureus strains. Significant genomic variability also was reported by Boerema et al. (5), who found 65 PFGE patterns ranging from 55 to $100 \%$ similarity for $92 \mathrm{~S}$. aureus isolates, including 62 enterotoxigenic strains.

In conclusion, the $S$. aureus isolates from mastitic cow's milk, bulk tank milk, and Minas frescal cheese have a diverse enterotoxigenic potential. The more recently described SE genes (seg through sell) predominated, with $s e g$ and sei the most common. Extensive variation in PFGE patterns also were found among the potentially toxigenic $S$. aureus isolates. Further investigations are needed to evaluate the production of these new toxins in milk and cheese and their significance for consumer safety.

\section{ACKNOWLEDGMENTS}

This work was financially supported by FAPEMIG (930-04; APQ 0639-3.12-07) and EMBRAPA (03.07.05.013.00). The authors gratefully acknowledge the contribution of Maria Aparecida V. P. Brito, who provided the $S$. aureus strains isolated from mastitic cow milk (belonging to the bacterial collection of Embrapa Dairy Cattle National Research Center).

\section{REFERENCES}

1. Barrow, G. I., and R. K. A. Feltham (ed.). 1995. Cowan and Steel's manual for the identification of medical bacteria, 3rd ed. Cambridge University Press, Cambridge.

2. Bennett, R. W., and G. A. Lancette. Staphylococcus aureus, chap. 12. In Bacteriological analytical manual, 8th ed. AOAC International, Gaithersburg, MD.

3. Bergdoll, M. S. 1997. Toxic shock syndrome. Rev. J. Venom. Anim. Toxins 1:6-21.

4. Blaiotta, G., D. Ercoline, C. Pennacchia, V. Fusco, A. Casaburi, O. Pepe, and F. Villani. 2004. PCR detection of staphylococcal enterotoxin genes in Staphylococcus spp. strains isolated from meat and dairy products. Evidence for new variants of $s e G$ and $\mathrm{seL}$ in $S$. aureus AB-8802. J. Appl. Microbiol. 97:719-730.
5. Boerema, J. A., R. Clemens, and G. Brightwell. 2006. Evaluation of molecular methods to determine enterotoxigenic status and molecular genotype of bovine, ovine, human and food isolates of Staphylococcus aureus. Int. J. Food Microbiol. 107:192-201.

6. Borelli, B. M., E. G. Ferreira, I. C. A. Lacerda, D. A. Santos, L. S. Carmo, R. S. Dias, M. C. C. Silva, and C. A. Rosa. 2006. Enterotoxigenic Staphylococcus spp. and other microbial contaminants during production of Canastra cheese, Brazil. Braz. J. Microbiol. 37:545-550.

7. Carmo, L. S., R. S. Dias, V. R. Linardi, M. J. Sena, D. A. Santos, M. E. Faria, E. C. Pena, M. Jett, and L. G. Heneine. 2002. Food poisoning due to enterotoxigenic strains of Staphylococcus present in Minas cheese and raw milk in Brazil. Food Microbiol. 19: 9-14.

8. Cremonesi, P., M. Luzzana, M. Brasca, S. Morandi, R. Lodi, C. Vimercati, D. Agnellini, G. Caramenti, P. Moroni, and B. Castiglioni. 2005. Development of a multiplex PCR assay for the identification of Staphylococcus aureus enterotoxigenic strains isolated from milk and dairy products. Mol. Cell. Probes 19:299-305.

9. Deplano, A., A. Schuermans, J. Van Eldere, W. Witte, H. Meugnier, J. Etienne, H. Grundmann, D. Jonas, G. T. Noordhoek, J. Dijkstra, A. van Belkum, W. van Leeuwen, P. T. Tassios, N. J. Legakis, A. van der Zee, A. Bergmans, D. S. Blanc, F. C. Tenover, B. C. Cookson, G. O'Neil, M. J. Struelens, and the European Study Group on Epidemiological Markers of the ESCMID. 2000. Multicenter evaluation of epidemiological typing of methicillin-resistant Staphylococcus aureus strains by repetitive-element PCR analysis. J. Clin. Microbiol. 38:3527-3533.

10. Dinges, M., P. M. Orwin, and P. M. Schlievert. 2000. Enterotoxins of Staphylococcus aureus. Clin. Microbiol. Rev. 13:16-34.

11. Fitzgerald, J. R., S. R. Monday, T. J. Foster, G. A. Bohach, P. J. Hartigan, W. J. Meaney, and C. J. Smyth. 2001. Characterization of a putative pathogenicity island from bovine Staphylococcus aureus encoding multiple superantigens. J. Bacteriol. 183:63-70.

12. Jarraud, S., M. A. Peyrat, A. Lim, A. Tristan, M. Bes, C. Mougel, J. Etienne, F. Vandenesch, M. Bonneville, and G. Lina. 2001. egc, A highly prevalent operon of enterotoxin gene, forms a putative nursery of superantigens in Staphylococcus aureus. J. Immunol. 166:669677.

13. Jorgensen, H. J., T. Mork, H. R. Hogasen, and L. M. Rorvik. 2005. Enterotoxigenic Staphylococcus aureus in bulk milk in Norway. $\underline{J}$. Appl. Microbiol. 99:158-166.

14. Katsuda, K., E. Hata, H. Kobayashi, M. Kohmoto, K. Kawashima, H. Tsunemitsu, and M. Eguchi. 2005. Molecular typing of Staphylococcus aureus isolated from bovine mastitic milk on the basis of toxin genes and coagulase gene polymorphisms. Vet. Microbiol. 105:301305.

15. Lange, C., M. Cardoso, D. Senczek, and S. Schwarz. 1999. Molecular subtyping of Staphylococcus aureus isolates from cases of bovine mastitis in Brazil. Vet Microbiol. 67:127-141.

16. Letertre, C., S. Perelle, F. Dilasser, and P. Fach. 2003. Identification of a new putative enterotoxin SEU encoded by the egc cluster of Staphylococcus aureus. J. Appl. Microbiol. 95:38-43.

17. Lina, G., G. A. Bohach, S. P. Nair, K. Hermits, E. Jouvin-Marche, and R. Mariuzza. 2004. Standard nomenclature for the superantigens expressed by Staphylococcus. J. Infect. Dis. 189:2334-2336.

18. Loncarevic, S., H. J. Jorgensen, A. Lovseth, T. Mathisen, and L. M. Rovik. 2005. Diversity of Staphylococcus aureus enterotoxin types within single samples of raw milk and raw milk products. $\underline{J \text {. Appl. }}$ Microbiol. 98:344-350.

19. Mehrotra, M., G. Wang, and W. M. Johnson. 2000. Multiplex PCR for detection of genes for Staphylococcus aureus enterotoxins, exfoliative toxins, toxic shock syndrome toxin 1 , and methicillin resistance. J. Clin. Microbiol. 38:1032-1035.

20. Morot-Bizot, S., R. Talon, and S. Leroy-Sétrin. 2003. Development of specific PCR primers for a rapid and accurate identification of Staphylococcus xylosus, a species used in food fermentation. $\underline{J}$. Microbiol. Methods 55:279-286.

21. Munson, S. H., M. T. Tremaine, M. J. Betley, and R. A. Welch. 1998. Identification and characterization of staphylococcal enterotoxin 
types G and I from Staphylococcus aureus. Infect. Immun. 66:33373348.

22. Nedelkov, D., A. Rasooly, and R. W. Nelson. 2000. Multitoxin biosensor-mass spectrometry analysis: a new approach for rapid, realtime, sensitive analysis of staphylococcal toxins in food. Int. J. Food Microbiol. 60:1-13.

23. Omae, K., D.-L. Hu, H. Takahashi-Omae, A. Nakane, and K. Shinagawa. 2003. Identification and characterization of a new staphylococcal enterotoxin-related putative toxin encoded by two kinds of plasmids. Infect. Immun. 71:6088-6094.

24. Omae, K., D.-L. Hu, H. Takahashi-Omae, A. Nakane, and K. Shinagawa. 2005. Comprehensive analysis of classical and newly described staphylococcal superantigenic toxin genes in Staphylococcus aureus isolates. FEMS Microbiol. Lett. 246:191-198.

25. Orwin, P. M., J. R. Fitzgerald, D. Y. M. Leung, J. A. Gutierrez, G. A. Bohach, and P. M. Schlievert. 2003. Characterization of Staphylococcus aureus enterotoxin L. Infect. Immun. 71:2916-2919.

26. Peles, F., M. Wagner, L. Varga, I. Hein, P. Rieck, K. Gutser, P. Keresztúri, G. Kardos, I. Turcsányi, B. Béri, and A. Szabó. 2007. Characterization of Staphylococcus aureus strains isolated from bovine milk in Hungary. Int. J. Food Microbiol. 118:186-193.

27. Pelisser, M. R., C. S. Klein, K. R. Ascoli, T. R. Zotti, and A. C. M. Arisi. 2009. Occurrence of Staphylococcus aureus and multiplex PCR detection of classic enterotoxin genes in cheese and meat products. Braz. J. Microbiol. 40:145-148.

28. Pereira, M. L., L. S. do Carmo, E. J. dos Santos, J. L. Pereira, and M. S. Bergdoll. 1996. Enterotoxin H in staphylococcal food poisoning. J. Food Prot. 59:559-561.

29. Rall, V. M. L., F. P. Vieira, R. Rall, R. L. Vieitis, A. Fernandes, Jr., J. M. G. Candeias, K. F. G. Cardoso, and J. P. Araújo, Jr. 2008. PCR detection of staphylococcal enterotoxin genes in Staphylococcus aureus strains isolated from raw and pasteurized milk. Vet. Microbiol. 132:408-413.

30. Reis, S. R., N. Silva, and M. V. Brescia. 2003. Antibioticoterapia para controle da mastite subclínica de vacas em lactação. Arq. Bras. Med. Vet. Zootec. 55:651-658.

31. Rosec, J. P., and O. Gigaud. 2002. Staphylococcal enterotoxin genes of classical and new types detected by PCR in France. J. Food Microbiol. 77:61-70.

32. Ross, T. L., W. G. Merz, M. Farkosh, and K. C. Carroll. 2005. Comparison of an automated repetitive sequence-based PCR microbial typing system to pulsed-field gel electrophoresis for analysis of outbreaks of methicillin-resistant Staphylococcus aureus. J. Clin. Microbiol. 43:5642-5647.

33. Růžičková, V., R. Karpíšková, R. Pantůček, M. Pospíšilová, P. Černíková, and J. Doškař. 2008. Genotype analysis of enterotoxin
H-positive Staphylococcus aureus strains isolated from food samples in the Czech Republic. Int. J. Food Microbiol. 121:60-65.

34. Sabioni, J. G., E. Y. Hiroaka, and M. L. R. Souza. 1988. Foodpoisoning from Minas-type cheese, contaminated with Staphylococcus aureus. Rev. Saude Publica 22:458-461.

35. Sabour, P. M., J. J. Jill, D. Lepp, J. C. Pacan, R. Ahmed, R. Dingwell, and K. Leslie. 2004. Molecular typing and distribution of Staphylococcus aureus isolates in eastern Canadian dairy herds. $\underline{J}$. Clin. Microbiol. 42:3449-3455.

36. Schmitz, F.-J., M. Steiert, B. Hofmann, J. Verhoef, U. Hadding, H.-P. Heinz, and K. Köhrer. 1998. Development of a multiplex-PCR for direct detection of the genes for enterotoxin $\mathrm{B}$ and $\mathrm{C}$, and toxic shock syndrome toxin-1 in Staphylococcus aureus isolates. J. Med. Microbiol. 47:335-340.

37. Tenover, F. C., R. D. Arbeit, R. V. Goering, P. A. Mickelsen, B. E. Murray, D. H. Persing, and B. Swaminathan. 1995. Interpreting chromosomal DNA restriction patterns produced by pulsed-field gel electrophoresis: criteria for bacterial strain typing. J. Clin. Microbiol. 33:2233-2239.

38. Todd, J. M., M. Fishaut, F. Kapral, and T. Welch. 1978. Toxic-shock syndrome associated with phage-group-I staphylococci. Lancet ii: $1116-1118$

39. U.S. Food and Drug Administration. 2001. Foodborne pathogenic microorganisms and natural toxins. Available at: http://www.fda.gov/ Food/FoodSafety/FoodborneIllnes/FoodborneIllnessFoodborne PathogensNaturalToxins/BadBugBook/ucm070015.htm. Accessed 2 October 2009

40. Vannuffel, P., J. Gigi, H. Ezzedine, B. Vandercam, M. Delmee, G. Wauters, and J. Gala. 1995. Specific detection of methicillin-resistant Staphylococcus species by multiplex PCR. J. Clin. Microbiol. 33: 2864-2867.

41. Wang, S.-C., C.-M. Wu, S.-C. Xia, Y.-H. Qi, L.-N. Xia, and J.-Z. Shen. 2009. Distribution of superantigenic toxin genes in Staphylococcus aureus isolates from milk samples of bovine subclinical mastitis cases in two major diary production regions of China. Vet. Microbiol. 137:276-281.

42. Weller, T. M. A. 2000. Methicillin-resistant Staphylococcus aureus typing methods: which should be the international standard? J. Hosp. Infect. 44:160-172.

43. Zafalon, L. F., A. Nader Filho, J. V. Oliveira, and F. D. Resende. 2007. Mastite subclínica causada por Staphylococcus aureus: custobenefício da antibioticoterapia de vacas em lactação. Arq. Bras. Med. Vet. Zootec. 59:577-585.

44. Zouharova, M., and D. Rysanek. 2008. Multiplex PCR and RPLA identification of Staphylococcus aureus enterotoxigenic strains from bulk tank milk. Zoonoses Public Health 55:313-319. 